\title{
A Study of the Impact of Marketing Mix for Attracting Medical Tourism in Jordan
}

\author{
Abdel Fattah Mahmoud Al-Azzam ${ }^{1}$ \\ ${ }^{1}$ Zarqa University, Jordan \\ Correspondence: Abdel Fattah Mahmoud Al-Azzam, Department of Marketing, Faculty of Economics and \\ Administrative Sciences, Zarqa University, Jordan. P. O. Box 132222, Zarqa 13132. Tel: 962-7-9096-8147. \\ E-mail: abdel_fattah1963@yahoo.com
}

$\begin{array}{ll}\text { Received: November 10, } 2015 & \text { Accepted: December 3, 2015 Online Published: January 28, } 2016 \\ \text { doi:10.5539/ijms.v8n1p139 } & \text { URL: http://dx.doi.org/10.5539/ijms.v8n1p139 }\end{array}$

This research is funded by Deanship scientific research and Graduate studies Zarga University, Jordan.

\begin{abstract}
Travel around the world for medical treatment is becoming further and further pronounced today. Furthermore, the basic premise of the medical tourism is that the care of the same or better quality of care, might be available in other countries, and acquired at a cheaper cost than in their country of origin (Jordan Tourism Board, 2015). Jordan, as one of the main destinations in medical tourism sector that is rapidly increasing, is developing worldwide trademark as "The Medical Hub of Middle East". These days several Middle Eastern countries such as Jordan, with a high potential for attracting medical tourism has been trying to enter this market. The objective of this study was to determine the marketing mix to attract medical tourism to Jordan and evaluated the actual potential foreign patients represented by cost, quality and other aspects of recognition of the role of government and relevant bodies in this market. Jordanian medical facilities according to special circumstances of Jordan can offer a huge potential for medical and health tourism and Jordan can become a hub of medical tourism in the area in future.
\end{abstract}

Keywords: marketing mix, quality, attracting medical tourism, hospitals in Jordan

\section{Introduction}

Medical costs are very high in developed such as USA, Western countries and Middle East. Due to the increase costs and high demand in their countries, people selecting to travel overseas in order to receive medical tourism (Ricafort, 2011). Medical tourism so it is a relatively new phenomenon and countries usually only grows in the Middle East and Asian countries are destinations for those who want medical tourism (Sharma, 2013). Frequently a medical tourism destination is the low-income countries with developing medical technologies and treatments. Medical tourism has become a more popular form of tourism. At the present, Jordan is a leader in medical tourism in the Middle East (MOTA, 2015). Furthermore, Jordan is a major destination for medical tourism with special knowledge and recognition around the world of medical tourism in Jordan. As a result, the current studies and developed theories on the topic are, minimum, leaving great chance for study in the area.

In spite of the lack of studies existing on the topic of medical tourism, in praxis, it is attracting attention as a growing sector of tourism. Particularly, Jordan aims to be a heart of medical excellence in the area, and is known for delivering high quality health care. Jordanian hospitals operating with the highest standards and have practitioners who are the best in their field of specialization. It is predicted that annual revenue generated from medical tourism in the Middle East could reach US \$4.4 billion in 2014 (Singh, 2014), and Jordan is well-placed to capture a main share of that figure. As noted, Egypt, Saudi Arabia, Tunis, Lebanon, and Dubai, are already actively promoting medical tourism. The main objective of this research is to examine, analyze, and explain the factors that influence the development of medical tourism in Jordan based on data collected from private and public hospitals, government bodies, institutions, and doctors. The findings will contribute to the literature by revealing the obstacles to the development of the medical tourism industry. They will also show of practical value to both Jordan and other state that are trying to develop this sector. In the last decade a number of Middle Eastern countries dominate the industry, but most countries have attempted to enter the market (Jordan Tourism 
Board, 2015). It is also important for developing countries further open their markets more significantly and provide enhanced opportunities for the industry (Delgoshaei, Ravaghi, \& Abolhassani, 2012).

In recent decades the medical tourism is a growing industry in the Middle East region and the countries are actively promoting it and others like Jordan had attempted to enter the market (Connell, 2006). According to news MOTA (2014), Jordan is a unique medical facility in the area that could provide great potential for medical tourism and health and Jordan can become a medical tourism hub in the region in the future. Additionally, Medical tourism has been grown incessantly in Jordan since $20^{\text {th }}$ century. In 2007, Jordan economy suffered from the world economy crisis which affected directly the tourism sector. The tourism Authority of Jordan, so, initiated the new marketing plan to promote tourism in the country and medical tourism became one of the main products of tourism in Jordan. Furthermore, there is no specific research on medical tourism in Jordan and the planning process. More specifically, this study is primarily focused on foreign medical tourists, who travel outside of their home country to receive different medical treatments in Jordan hospitals. The questionnaires were distributed to international patients who came for medical treatment in the four famous hospitals in Jordan. However, the purpose of this study is to determine the impact of marketing mix that lead international medical tourists to select hospitals in Jordanian as their medical tourism destination. Finally, the findings of this research will be applied as a guideline for medical tourism program in Jordan. Due to the lack of studies in this specific theme, this research would be helpful for other studies, students, and government organizations and experts in medical tourism field.

Therefore, the following four hypotheses are proposed on the basis of above literature analyses:

Hypothesis 1: There is a significant positive relationship between product and attraction of medical tourism.

Hypothesis 2: There is a significant positive relationship between place and attraction of medical tourism.

Hypothesis 3: There is a significant positive relationship between price and attraction of medical tourism.

Hypothesis 4: There is a significant positive relationship between promotion and attraction of medical tourism.

\section{Literature Review}

Destination Jordan' is famous for its tourist offer and he has appeared as a popular medical tourism destination because of its ability to offer high quality care at low cost. Furthermore, medical tourism is a link that healthcare and travel. In today's world economy, the concept of medical tourism is not new but rather a rising tendency for many. In addition, the medical tourism development has been made well-known for the USA, Middle East, British and other patients in rising economies who travel abroad in explore for low-cost high quality medical treatments (Piazolo \& Zana, 2011). Moreover, the main objective of international patients involved in medical tourism is to have admission to the highest quality health care from hospitals that are internationally recognized around the world at the cost of more affordable medical treatment (Azadi et al., 2012). Particularly, this study aims to determine the factors effective in attracting medical tourism to Jordan in different aspects such as real function relevant organizations, the right marketing mix according to the special circumstances of Jordan. It appears that each of these factors determine the need for Jordan to enter the medical tourism market. Thus, this study is of special significance for evaluating the function of the organization responsible, factors right marketing mix and recognizes the state of Jordan in accordance with the special geographical location of Jordan. It is significant to know this study have led to increasing public awareness of the importance and special factors to attract medical tourists in Jordan. Furthermore, studying different factors like as promotion, place, product, price and quality play a vital role in the tourism industry.

\subsection{Medical Tourism}

In the early phases of medical tourism, several studies including spa treatments and relax in the category of medical tourism because of the difficulty to differentiate between health and medical tourism (Bindu \& Kanagaraj, 2013). Recent study discriminate medical tourism as tourism that contains specific medical intervention. Also, medical tourism refers to people who live in one country and travel to another country in order to receive medical, dental and surgical care while at the same time receiving equal to or greater care than they would have in their own country, and are traveling for medical care because of affordability, better access to care or a higher level of quality of care (Medical Tourism Association, 2015). Connel (2006) defined medical tourism as "tourism deliberately related to direct medical intervention, and results are expected to be considerable and long term." On the other hand, Baukute (2012), medical tourism has two main models: surgical and therapeutic. Surgical tourism is a tourism that contains operations, whereas therapeutic is tourism that helps healing treatments. Therapeutic tourism shares some resemblance with surgical tourism such as medical checkups and diagnosis, but is distinguish in the actuality it is frequently a long stay or requires repeat visits. 
Today many authors such as Connell (2006) describe medical tourism as a popular mass culture "where people travel frequently-long distance to abroad destinations such as (India, Thailand, Malaysia) to get medical dental and surgical care while at the same time being holidaymakers, in a more conventional sense. In contrast, medical tourism can be generally defined as provision of cost efficient private medical care in cooperation with the tourism industry for patients needing surgical and other models of specialized treatment (Kazemi, 2008). Finally, medical tourism defined in several studies, as the act of traveling to other countries to get medical treatment, dental, and surgical care or where people travel to other countries to get medical care maybe contains complementary (alternative) and traditional medicine like (spa water or climate, black mud stone, sand.). In this research, medical tourism is described as tourism that includes direct medical intervention, whether for surgery and therapy. Such interventions require medical tourists to by chance visit a specific destination for medical treatment.

\subsection{Medical Tourism in Middle East}

As one of the major sources of medical tourists, the Middle East, especially Jordan, but also Egypt and Lebanon have recently tried to reverse this trend and develop medical tourism industry itself. Also, Jordan is one of the main destinations of medical travelers in the Middle-East region. Based from a statistic on Ministry of tourism and antiquities (2014), Jordan received around $85 \%$ of medical tourists from the Middle-East region, followed by Egypt and Lebanon at 10\% each, and others at 5\% in 2014. Most international patients come from neighboring countries with less developed medical infrastructure such as Egypt, Lebanon and other developed countries from the UAS, British, and Asia (Al muala, 2012). Due to the political instability in Syria, Iraq, and Yemen as well as dollars high exchange rate, most of the international medical tourists come from neighboring countries in Middle-East. Finally, Jordan has been the popular medical destination for the Middle East. Its proximity to the Middle East and the relatively low travel costs, have been attracting all countries in Middle East and USA. Jordan is unique as it provides holistic medicinal services such as Stomach surgery, cosmetic surgery, eye exams, heart surgeries and routine checkups are among the major services that Gulf countries and European countries are looking in Jordan (Hansen, 2008).

\subsection{Elements of the Marketing Mix}

Nowadays, it is recognized that not only sufficient just to use the marketing mix, but it also needs to be adjusted each time a change in consumer demand, which requires them (Froelich, 2012). Each company has focused on customers' requires discovering suitable marketing mix. The marketing mix consists of four main elements: product, price, promotion and place. This 4Ps are the four major decision areas that marketers need to manage it so that they meet or exceed the needs of customers better than the competition (Kazemi, 2008). The marketing mix is a set of controlled variables that organizations use to influence the target market. Four Ps have long been the foundation of the marketing strategy in most industries and is increasingly regarded by health care organizations (Vasiliki, 2012). Finally, marketing mix is one of the most famous of all marketing model. These four variables are used to analyze the impact of customer choice to choose the hospitals in Jordan for medical treatment. Below follows the implementation of the 4 Ps to health services.

\subsubsection{Product}

Product is a significant aspect of developing a competitive offer within the medical tourism market. It is significant to recognize that consumers above all are demanding the benefits of the products offer and not the products or features of the products per se (Smith \& Puczko, 2009). Furthermore, the customer look for satisfaction of needs, and these needs are very varied. Also, a product as defined by Kotler et al. (2006) is anything that can be offered to a market for attention, acquisition, use, or consumption that might satisfy a want or need. Lee (2006) found that the product is the core of the marketing mix strategy where retailers can provides unique attributes that distinguish their product from their competitors. In contrast, in the medical sector, the product represents goods, services, or ideas provided by a healthcare organization (Spasojeric \& Susic, 2010). The product is hard to exactly be defined in healthcare, creating a challenge for healthcare marketers. While, on the other hand, it is more difficult to quantify services and customers assess them differently from more tangible products. Medical services have changed and nowadays it is not necessary the customer himself who searches from medical treatment but it can be the other way round (Burkett, 2007). Finally, Product in this research defines to the medical treatment and services offered by the hospitals in Jordan. Moreover, it refers to the internationally accredited hospitals in Jordan that provides quick services, superb hospital facilities, high technology medical equipment, top-notch doctors and nurses and excellent patient care services.

\subsubsection{Place}

Place contains decisions regarding the distribution channels to be applied and their management, the locations of 
channels, ways of transportation and inventory levels to be held (Ariwa \& Syvertsen, 2010). Furthermore, the aim is to make certain that products and services are obtainable in the proper qualities, at the right time and place (Birschel, 2009). Distribution channels contain firms such as retailers or wholesalers through which goods pass on their way to consumers (Bookman \& Bookman, 2007). On the other hand, Place in the medical sector can describe to the location or the hours a medical service can be accessed. As in previous years a physician could setup an office in a location suitable for him, today the customers increasingly dictates the role of place in the marketing mix. Finally, in medical tourism industry in Jordan, the place describes, to the hospital's location near tourist attraction and shopping centers, accessibility to local transportation, situated in a famous city, sited in a safe and secured environment, and role in a calm location.

\subsubsection{Price}

Price in general is a main factor of the marketing mix because it represents a foundation what the firm receives for the product or service which is being marketed. Furthermore, Kotler et al. (2009), define price is the amount of money pays for a product or service, or the total values that consumers exchange for the benefits of having or using the product or service. Also, due to the intangible nature of services, price becomes an important quality indicator where other information is lacking or absent (Zeithaml, 1988). Also, price is regarded as the most significant measurement of repurchase intentions (Saiprasert, 2012; Vasiliki, 2012). Furthermore, the price of a product or service must reflect the customer's willingness to pay (Hall \& Janes, 2011). Particularly, in medical tourism sector, the price refers to the affordability of the diverse medical process in Jordan compared to a patient's home country. This contains the cost of an added benefit of a holiday tour in an interesting destination after a medical treatment. Finally, price in this research indicates to the affordability of medical treatment costs along with travel tours after the medical treatment in Jordan. Price indicates the cost saving chance that medical travelers receive when they travel to Jordan for medical treatment.

\subsubsection{Promotion}

Another factor that impacts on attracting medical tourism is promotion. This factor is regarded in marketing literature as a significant factor essential for the creation, building and success of medical tourism industry in Jordan (Al-hroot, 2007). Promotion is one of the key elements of 4Ps in the marketing mix (Dibb et al., 1994) and obviously plays a fundamental role in building successful attracting medical tourism. Importantly, promotion plays a competitive advantage in destination marketing for attracting medical tourism (Vasiliki, 2012). Regarding to medical tourism services in Jordan, promotion is a technique used to communicate the features and benefit of a product or service to the consumers (Al-hroot, 2007). A marketer may use diverse strategies in order to develop product or service awareness to the chosen target markets. Furthermore, promotion is the effort to inform and persuade potential consumers in order to accomplish the sale of the product, services, or ideas (Mugomba \& Danell, 2007). Also, promotion includes all this activities such as advertising, personal selling, public relations, publicity that are intended to stimulate customer demand and develop the marketing performance of sellers'(Al Azzam, 2012; Kumar \& Komaraian, 2014). Finally, in this research, the promotion referred to the extra services such as airport service and visa extensions, special rates for hotel accommodation, insurance plan coverage and claims, special price on various medical treatment packages, and special rates for travel tours after medical treatment.

\subsection{Framework}

This research used quantitative marketing research methods to thoroughly discover the variables that lead medical tourist to select hospitals in Jordan for their medical needs. Furthermore, quantitative research techniques were initially explored in the natural sciences to study natural phenomena (Ricafort, 2011). In addition, to develop mathematical models, theories and / or hypotheses related to this phenomenon is the main goal of quantitative study. Furthermore, the quantitative techniques can be applied to confirm hypotheses of a research study. However, the quantitative research model uses questionnaires and scales. Questionnaires give the chance to collect large amounts of data from several respondents (Koster, 2009; Jabarri, 2007). In this research, an examination and analysis of the motivational variables of patients in selecting a facility for medical treatment were identified through the applied of survey questionnaires. A hypothesis were explored and analyzed through the applied of Statistical Package for the Social Sciences (SPSS). There are two sets of variables: (1) Independent Variables and (2) Dependent Variables. The Independent Variables contained of the general information of the respondents, which included quality of medical services, product of medical services, pricing of medical services, promotion of medical services, place of medical service. In contrast, the Dependent Variables contain attractions of medical tourism. 


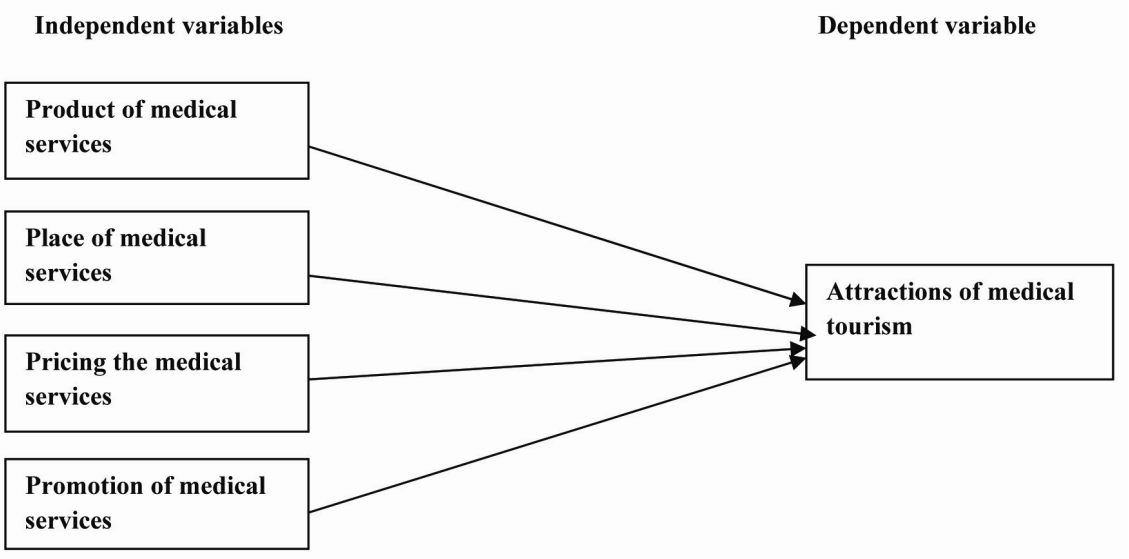

Figure 1. Theoretical framework

\section{Research Methodology}

The main objective of this study is to explain the procedures performed in determining the necessary variables that motives patients international to select hospitals in Jordan as their medical tourism destination. Many descriptive studies has been conducted to explain the relationship between variables involved and to illustrate why some variables are regarded more significant than the others. However, the data in this research were drawn from two sources, primary data and secondary data. Primary data is gathered through filling questionnaire in four hospitals of Jordan. Secondary data obtained is literature or references that are intended to support studies. Furthermore, this study covers the research design, target population, sample size, and data analyses.

\subsection{Research Design}

An appropriate research method is essential to the success of the study project (Sekaran, 2003). It is necessary for determining the type of data, data collection method, and sampling methodology that was used to accomplish the study aims (Burns \& Bush, 2002; Cooper \& Schindler, 2006a). This study was performed in order to examine the variables that influence on attractions of medical tourism to Jordan. In addition, research methodology is more easily defined as qualitative or quantitative, but the most significant is that the method chosen must complete the research questions and objectives being investigated (Sekaran, 2006). Mainly, this technique was to describe the profile of the international medical tourists, the collection of primary data was accomplished using a survey method instrument to answer the study's questions. The unit of analysis of this research is individual international medical tourist. Individual international medical tourists were selected because they were considered the most important market segment for the Jordanian medical tourism industry due to their tendency to stay longer and be big spenders during their visit to Jordan (Churchill \& Brown, 2004).

\subsection{Target Population}

Population is a comprehensive collection of data contains all subjects of interest in the properties related to the research study reviewed and analyzed. The population that is being studied is also called the target population (Saiprasert, 2011). Furthermore, the target population of the research was the international medical tourists travelling to Jordan looking for medical services in chosen hospitals in Amman, located in Jordan during August 2015-October 2015. The destination chosen was based on the literature review that Jordan is a main hub of medical tourism in Middle East. The number of international visitors who used healthcare in Jordan was 250.000 thousand in the year 2014 and increased to 400 thousand in 2015, which was a $13 \%$ increase. It was estimated that in 2016, there would be 15\% increase (Ministry of Tourism and Antiquities, 2015). Jordan is able to attract such a large number of patients because it is well-known as a tourist paradise, with many tourist attractions available for recuperating patients, the relatively low cost of living, friendly locals and expats who respected quality health care. The country has about 106 private and government hospitals nationwide (Ministry of Tourism and Antiquities, 2015). The research excluded business expatriates and foreign respondents who already resided in Jordan.

\subsection{Sample Size}

Sample size is a very significant issue because samples that are too big my waste time, resources and money, whereas samples that is too small may lead to in precise results. However, a sample is a section of the population 
of importance, a sub-collection chosen from a population. Because the accurate number of the whole population is unknown, samples of this study were chosen through the convenience sampling method. Furthermore, the sample size should rely on the target population size and the importance of the research. However, there are 106 hospitals recognized by the Ministry of Tourism and Antiquities in Jordan. The researcher then divided the country into three regions (north, middle, and south). Hence, this study focuses on four hospitals in Amman city in the middle region is regarded justifiable. But, there are general rules; 200 cases are adequate for researches in which statistical analysis is to be done (Cooper \& Schindler, 2006b; Hohmann, 2006). The researcher distributed 200 questionnaires to the selected respondents. The questionnaires were distributed to international tourists who were traveling to Jordan for medical goals to obtain medical treatments at Jordanian Hospitals from August-2015-October-2015. While there are no fixed standards in the literature about the relation between sample size and path model complexity, the following recommendations were offered. Tabachnick and Fidell (1996) suggest that, "it is comforting to have at least 200 cases for factor analysis" (p. 640). Similarly, Hair et al. (2007) suggest a ratio of 10 cases to one questionnaire item for the purpose of factor analysis. The expected number of sample size was at least 200 or more to meet the recommendation criteria. The sample size of this research was 200 which met the recommendation criteria. Finally, the summary of the sample collected to each hospitals are given in the following Table 1.

Table 1. Type of hospitals

\begin{tabular}{lll}
\hline & Hospitals & Number of Respondents \\
\hline 1 & Especialty Hospital & 50 \\
2 & Istiklal Hospital & 50 \\
3 & Islamic Hospital & 50 \\
4 & King Hussein Hospital Center & 50 \\
\hline Total & 4 & 200 \\
\hline
\end{tabular}

\subsection{Data Analysis}

In order to analyze the gather data, we should change them into precious information by applying statistical tests. In fact, in any study, data analysis is one of the most significant parts. In this study, researchers used SPSS software applications. Furthermore, Quantitative analysis was conducted using SPSS 18.0 (Statistical Package for Social Sciences) for Windows. The data from the completed survey has been entered, checked and processed by statistical package chosen. More particularly, in the first phase of data analysis, the data gathered from the four Hospitals were checked for missing values, outliers and data entry errors. Moreover, descriptive characteristics of respondents are then conducted applying frequencies and percentages in the package. Finally, this research used dissimilar types of statistical method as appropriate. Non-parametric methods were examined to analyze the data, such as: reliability analysis, frequencies and percentages, and mean score; and parametric method, such as, multiple regression analysis to evaluate if there is a relationship (or not) between the marketing mix and Attractions of medical tourism to Jordan.

\section{Result}

\subsection{Descriptive Statistics}

Descriptive statistics indicated to the transformation of raw data into a shape that will offer information to illustrate a set of variables that will make them easier to understand and interpret (Hair et al., 2006). Additionally, descriptive analysis is a univariate analysis which contains of diagrams, frequency tables, dimensions of central tendency (mean, median, and mode) and dimensions of dispersion (Hair et al., 2007). In this research a descriptive method has been used to organize, explain, and summarize data to get an overview of the diverse characteristics of the sample structure and distribution. Finally, Descriptive statistics for the final list of factors of the research are demonstrated in Table 1. For ease of interpretation, the range of five point Likert-scales was categorized in to equal sized categories of low, moderate, and high. Hence, scores of less than 2.5 is considered as low; scores of 2.5 to 3.5 is considered as moderate, and scores more than 3.5 is considered as high. Table 1 shows the result. 
Table 2. Means and standard deviations

\begin{tabular}{lll}
\hline Component & Mean & Std. Deviation \\
\hline Product & 4.18 & 1.204 \\
Place & 4.04 & .777 \\
Price & 4.29 & .776 \\
Promotion & 4.52 & 1.350 \\
Attraction medical tourism & 4.44 & .610 \\
\hline
\end{tabular}

\subsection{Scale Reliabilities}

Cronbach's alpha is an evaluating for a form or survey's internal consistency. Called the reliability coefficient scale is sometimes note that the reliability coefficient of 0.70 or higher is regarded acceptable in many situations of social science studies. For this reason, one of the techniques for reliability was estimate by Cronbach Alfa in this research. Furthermore, Cronbach's alpha is used for measuring the internal consistency, and thus of reliability (Pallant, 2003). According to Hair et al. (2006), explored the reliability values less than .60 is considered to be poor and those in the .70 are acceptable and those over .80 are good. In this study, Cronbach's alpha has been applied to measurement the reliability of the items. As it is demonstrate below, the calculated Cronbach's alpha is between .740 and .830 which is a very good result

Table 3. Reliability analysis

\begin{tabular}{lll}
\hline Variables & Number of items & Alpha \\
\hline product & 4 & .740 \\
place & 4 & .770 \\
price & 4 & .780 \\
Promotion & 4 & .80 \\
Attractions of medical tourism & 4 & .830 \\
\hline
\end{tabular}

\subsection{Multiple Regression Analysis}

Multiple regression analysis is a further sophisticated expansion of correlation and is used to discover the predictive ability of a set of independent factors on one dependent factor (Pallant, 2007). In order to evaluate the hypotheses developed in the current research, multiple regression analysis was performed. To examine which factors have the most impacts on Attractions of medical tourism, we used the beta values as shown in Table 3 . Based on the beta values of the five significant factors, the predictor factors that exercise the most impacts on Attractions of medical tourism is: product $(\beta=.360)$, followed by place $(\beta=.279)$, price $(\beta=.220)$, and promotion, $(\beta=.211)$.

Table 4. Result of multiple regressions between product, place, price, promotion, quality and attractions of medical tourism

\begin{tabular}{llll}
\hline Model & & \multicolumn{2}{l}{ Dependent variable: customer loyalty } \\
\hline Independent variable & $\mathrm{B}$ & $\mathrm{Beta}$ & $\mathrm{Sig}$ \\
Product & .360 & .423 & .000 \\
Place & .279 & .317 & .000 \\
Price & .220 & .238 & .000 \\
Promotion & .211 & .189 & .000 \\
\hline R Square $=.796$ & & &
\end{tabular}

\subsection{Correlation of Analysis}

It investigates the relationship between factors that explain the direction and degree of association between them. Furthermore, a correlation matrix contains of the values of the correlation coefficients for the factors involved (Robson, 2002; Bryman, 2008). In this research, Pearson correlation coefficient was applied to investigate the relationship between research factors. At first it was targeted to discover the value and the direction of the relationships between independent and dependent variables. Table 5 offers a summary of the correlation analysis findings. The computation of the Pearson correlation coefficients was conducted to get an understanding of the relationship between all the factors in the research. The values of the correlation coefficients (r) given in Table 5 
demonstrate the strength of the relationship between factors. As demonstrate in Table 5 overall correlation values of the factors indicate correlation coefficients with positive values above .560 .

Table 5. Pearson correlation for independent variables and dependent variable

\begin{tabular}{|c|c|c|c|c|c|}
\hline & Attraction & Product & Place & Price & Promotion \\
\hline Attraction & 1 & & & & \\
\hline Product & $.816(* *)$ & 1 & & & \\
\hline Place & $640(* *)$ & $.560(* *)$ & 1 & & \\
\hline Price & $765(* *)$ & $.609(* *)$ & $591(* *)$ & 1 & \\
\hline Promotion & $.780(* *)$ & $.653(* *)$ & $.667(* *)$ & $.645(* *)$ & 1 \\
\hline
\end{tabular}

\subsection{Hypothesis Test}

All the data below were got through the development in Statistical Package for Social Science (SPSS) version 18.0 software in order to investigate the hypothesis in this research. The primary data were gathered through questionnaires that distributed to the patients. The data gathered had been fundamental into this software and analyzed by applying multiple regression analysis techniques. It comprise all the factors that were applied in this research, which are product, place, price, promotions, service quality, and attracting medical tourism for dependent factors. The investigated of these hypotheses leads to the achievement of research objectives. The suitable marketing mix which are related to medical tourism issues to Jordan which is supported by sub hypothesis that comprise: the diversity of medical tourism services, the product of medical services, the price of medical service, and promotion of medical services, are the effective variables for attracting medical tourists in Jordan. Finally, the result is consistent with the findings of previous studies such as (Sarwar, 2013; Kyritsis, 2014; Ricafort, 2013).

\section{Discussion and Conclusion}

The purpose of this research was to investigate the marketing mix affecting the customers' preference in selecting hospitals in Jordan for medical treatment. The research sought to assess the respondents' perceptions with regard to the level of importance of factors affecting their decision in opting for health care treatment in Jordan. More specifically, medical tourism in Middle East is increasing quickly. As several countries in Middle East are offering medical service, therefore, Jordan needs a lot of development in order to be the regional hub for medical tourism. As medical tourism is a part of the overall service sector, thus, patients are the core for this business to develop. However, prior studies have concluded numerous factors variables that motivate patients to search for health care services in foreign countries. According to Smith \& Forgione (2008), explored "Product" and "Price" are the necessary factors that influence the choice of international health care facility. At the same time, McKinsey \& Company (2008) study demonstrated that "Product" is the sole factor that drives medical travelers to seek medical treatment overseas. In contrast, Deloitte Development (2008) study mentioned that medical tourists are selecting to offshore their medical needs primarily because of "Price", wherein cheaper medical treatment can be explored in numerous appearing medical tourism destinations worldwide. Based from these prior studies, this study aims to determine whether "Product" or "Price" is the necessary variable that leads international medical tourists to select Jordan hospitals for health care services. However, the results of this research identified key dimensions for medical tourism to be sustained in Jordan. Although, the results confirm that Jordan government's effort in promoting their destination image is fairly effective, however, there is always room for enhancement if they want to compete in this medical tourism field. This result is consistent with that demonstrated by previous studies (Helble, 2011; Johnston, 2010; Sarwar, 2013). Furthermore, the effective promotional activities by the Jordanian government together with other private organizations have also impacted a number of medical tourists to visit Jordan which is also related to the previous results (Ricafort, 2011; Vasifiki, 2012). In terms of service quality, most of the patients are satisfied with the current services provided by the Jordanian hospitals. This result is consistent with that demonstrated by previous studies (Saiprasert, 2011; Spasojevic \& Susic, 2011). Though, interestingly, the study revealed that in Jordan, the current practice of customer service is not very high. It has provided the necessary instructions for hospitals in Jordan to seriously look into the matter and think of a solution in retaining and attracting prospective medical tourists in the near future. Finally, medical tourism in Jordan has appeared as the fastest growing segment of tourism industry despite the global economic downturn. Jordan is providing very low cost treatments not only to Jordanian but also to the foreigners. Patient from Arabs, Europe, Americans and UK, are coming to Jordan to search for 
alternative and cost-effective destinations to obtain their treatments done. The Jordan medical tourism sector is currently at a blossoming stage, but has a huge potential for future growth and improvement. Finally, this research contributes to the theoretical improvement in the tourism sector by providing the structured relationship between different aspects contributing towards the progress of medical tourism in Jordan. In contrast, this research can help a number of studies in the hospitality and Medical sector and the people involved in such industry that can apply this research results as an example for understanding on how a place, price, product, promotion, service quality and better customer service has strong impacts on the customers' perception and attitude towards the medical tourism aspects towards Jordan.

\section{References}

Al Azzam, A. (2012). The direct and indirect effect of predictor variables on destination brand loyalty. University Utara Malaysia.

Al muala, A. (2012). Assessing the Relationship between Marketing Mix and Loyalty through Tourist Satisfaction in Jordan Curative Tourism. American Academic \& Scholarly Research Journal, 4(2).

ALhroot, A. (2007). Marketing of a destination. UK: Hudders field university.

Ariwa, E., \& Syvertsen, C. (2010). Informatization of Economic Growth in the Health-tourism Industry in Montenegro Using Insights from Regionalization. Journal of Internet Banking and Commerce, 15(1), 1-16.

Ayoubian, A., Tourani, S., \& Hashemi Dehaghi, Z. (2013). Medical Tourism Attraction of Tehran Hospitals. International Journal of Travel Medicine and Global Health, 1(2), 95-98.

Azadi, F., Maleki, M., \& Azmal, M. (2012). A Medical Tourist Perception of Iranian Hospital Quality: Limited Employee Foreign Language Skills Negatively Impact Communication. International Journal of Hospital Research, 1(2), 85-90.

Baukute, G. (2012). Medical tourism: the analysis of positive aspects of establishing medical tourism sector in Lithuania. Thesis published, Central European University.

Bindu, T., \& Kauagaraj, C. (2013). An Analysis of Push and Pull Travel Motivations of Domestic Tourists to Kerala. IJMBS, 3(2).

Birschel, D. (2009). Medical Tourism. Benefits Quarterly, 25(2), 67.

Bookman, M. Z., \& Bookman, K. R. (2007). Medical Tourism in Developing Countries. New York: Palgrave Macmillan. http://dx.doi.org/10.1057/9780230605657

Bryman, A. (2008). Social Research Methods. Oxford: Oxford University Press.

Burkett, L. (2007). Medical Tourism: Concerns, Benefits and the American Legal Perspective. Journal of Legal Medicine, 2. http://dx.doi.org/10.1080/01947640701357763

Burns, A., \& Bursh, R. (2002). Marketing research: on line research applications (4th ed.). New Jersey: Prentice Hall.

Churchill, G. A., \& Brown, T. J. (2004). Basic Marketing Research. Mason, OH: Thompson South-Western.

Connell, J. (2006). Medical tourism: Sea, sun, sand and ...surgery. Tourism Management, 27, 1093-1100. http://dx.doi.org/10.1016/j.tourman.2005.11.005

Cooper, D., \& Schindler, P. (2006a). Business research methods (9th ed.). New York: McGraw Hill.

Cooper, D., \& Schindler, P. (2006b). Marketing research (3rd ed.). New York: McGraw-Hill/Irwin.

Delgoshaei, B., Ravaghi, H., \& Abolhassani, N. (2012). Importance-Performance Analysis of Medical Tourism in Iran from Medical Tourists and Medical Services Provider's Perspective. Middle-East Journal of Scientific Research, 12(11), 1541-1547.

Deloitte Development LLC. (2009). Medical Tourism: Update and implications.

Dibb, S., Simkin, L., Pride, W., \& Ferrell, O. (1994). Marketing: concepts and strategies (2nd European ed.). Houghton miff line.

Froelich, N. (2012). Medical Tourism A study about motivational factors and the prerequisites for creating a competitive offer-with a Swedish perspective. Thesis published, Södertörn University.

Hair, J., Black, B., Babin, B., Anderson, R., \& Tatham, R. (2006). Multivariate data analysis. Upper Saddle River, NJ: Pearson prentice hall. 
Hair, J., Money, A., Samouel, F., \& Page, M. (2007). Research method of business. Chichester: John Wiley and Sonsltd.

Hall, M., \& James, M. (2011). Medical tourism: Emerging biosecurity and nosocomial issues. Tourism review, 66(12), 118-126. http://dx.doi.org/10.1108/16605371111127288

Hansen, F. (2008). A revolution in healthcare Medicine meets the marketplace.

Helble, M. (2011). The movement of patients across borders: challenges and opportunities for public health. Bull World Health Organ, 89, 68-72. http://dx.doi.org/10.2471/BLT.10.076612

Hohmann, U. (2006). Quantitative Methods in Education Research. Retrieved from http://www.edu.plymouth.ac.uk/resined/Quantitative/quanthme.htm

Jabarri, A. (2007). Planning the proper programmer for attracting medical tourism in Iran. Thesis published, Tehran University.

Johnston, R. (2010). What is known about the ef-fects of medical tourism in destination and de-parture countries? A scoping review. Int J Eq-uity Health, 9, 17-24. http://dx.doi.org/10.1186/1475-9276-9-24

Jordan tourism Board. (2015). Retrieved from http://www.mota.gov.jo/contents/Jordan_Tourism_BoardAr.aspx

Kazem, Z. (2008). Study of the effective factors for attracting medical tourism in Iran. Thesis published, Lulea University of Technology.

Koster, K. (2009). Spurred by economy, medical tourism poised for breakout in '09. Employee Benefit News, 23(2), 38.

Kotler, P., \& Armstrong, W. (2009). Principles of marketing (5th ed.).

Kumar, V., \& Komaraiah, J. (2014). Role of Indian Railways in Promotion of Tourism in India: A Case Study of Foreign Tourists. Journal of Humanities and Social Science, 19(1). http://dx.doi.org/10.9790/0837-19192232

Kyritsis, F. N. (2012). Medical Tourism, A study about motivational factors and the prerequisites for creating a competitive offer-with a Swedish perspective. Thesis published, Södertörn University.

Lee, C. (2006). Medical tourism, an innovative opportunity for entrepreneurs. Journal of Asia entrepreneurship and sustainability, 3(1), 12.

Lee, C., \& Spisto, M. (2007). Medical tourism, the future of health services. Going for Gold $\sim$ Best Practices in Ed. \& Public, 7(7), 1-7.

Medical Tourism Association. $\quad$ (2013). $\quad$ Retrieved from http://www.medicaltourismassociation.com/en/2013-mta-survey-report.html

Medical Tourism Association. (2015). Retrieved http://www.medicaltourismassociation.com/en/2013-mta-survey-report.html

MoTA. (2014). Jordan national tourism strategy. Amman: Ministry of Tourism and Antiquities.

MoTA. (2015). Statistics Department. Amman: Ministry of Tourism and Antiquities.

Mugomba, C., \& Danell, S. (2007). Medical Tourism and its Entrepreneurial Opportunities-A conceptual framework for entry into the industry. Goteborg University.

Pallant, J. (2007). SPSS survival manual: a step by step guide to data analysis using SPSS for windows. Crows vest: Allen and Unwin.

Piazolo, M., \& Zana, N. A. (2011). Medical Tourism-A Case Study for the USA and India, Germany and Hungary. Acta Polytechnica Hungarica, 8(1).

Ricafort, K. (2011). A study of the influencing factors that lead medical tourists to choose Thailand hospitals as medical tourism destination. Thesis published, Webster University.

Saiprasert, W. (2011). An examination of the medical tourists motivational behavior and perception: A structural model. Thesis published, Oklahoma State University

Sarwar, A. (2013). Medical Tourism in Malaysia: Prospect and Challenges. Iranian J Publ Health, 42(8), 795-805.

Sekaran, U. (2003). Research methods for business: a skill building approach (4th ed.). New York: John Wiley and sons. 
Sekaran, U. (2006). Research methods for business: a skill building approach. New Delhi: Wiley India.

Sekaran, U. (2007). Research methods for business: A skill-building approach (4th ed.). New Delhi: John Wiley and sons.

Sharma, A. (2013). Medical tourism: emerging challenges and future prospects. International Journal of Business and Management Invention.

Singh, L. (2014). An evaluation of medical tourism in India. African Journal of Hospitality, Tourism and Leisure, $3(1)$.

Smith, M., \& Puczko, L. (2009). Health and wellness tourism. London: Elsevier Butterworth Heinemann.

Smith, P., \& Forgione, D. (2008). Global Outsourcing of Healthcare: A Medical Tourism Decision Model. Retrieved from http://business.utsa.edu/wps/acc/0033ACC-205-2008.pdf

Spasojevic, M., \& Susic, V. (2011). Development perspectives of new destinations in medical tourism. International journal of Business, Management and Social sciences, 2(3), 9-13.

Tabachnick, B., \& Fidell, S. (1996). Using multivariate statistics. New York: Harper Collins.

Vasifiki, P. (2012). Exploring and exploiting medical tourism opportunities in Greece. Thesis published, University of Patras.

Zeithmal, V. A. (1988). Consumer perceptions of price, quality and value: A means-ends model and synthesis of evidence. Journal of Marketing, 52(July), 2-22. http://dx.doi.org/10.2307/1251446

\section{Copyrights}

Copyright for this article is retained by the author(s), with first publication rights granted to the journal.

This is an open-access article distributed under the terms and conditions of the Creative Commons Attribution license (http://creativecommons.org/licenses/by/3.0/). 